\title{
The Xenopus Brachyury promoter is activated by FGF and low concentrations of activin and suppressed by high concentrations of activin and by paired-type homeodomain proteins
}

\author{
Brancko V. Latinkić, Murie Umbhauer, ${ }^{1}$ Kathy A. Neal, Walter Lerchner, James C. Smith, ${ }^{3}$ and \\ Vincent Cunliffe ${ }^{2}$
}

Division of Developmental Biology, N ational Institute for Medical Research (NIMR), The Ridgeway, London N W7 IAA, UK

\begin{abstract}
The mesoderm of Xenopus laevis arises through an inductive interaction in which signals from the vegetal hemisphere of the embryo act on overlying equatorial cells. One candidate for an endogenous mesoderm-inducing factor is activin, a member of the TGF $\beta$ superfamily. Activin is of particular interest because it induces different mesodermal cell types in a concentration-dependent manner, suggesting that it acts as a morphogen. These concentration-dependent effects are exemplified by the response of Xbra, expression of which is induced in ectodemal tissue by low concentrations of activin but not by high concentrations. Xbra therefore offers an excellent paradigm for studying the way in which a morphogen gradient is interpreted in vertebrate embryos. In this paper we examine the trancriptional regulation of Xbra2, a pseudoal lele of Xbra that shows an identical response to activin. Our results indicate that 381 bp $5^{\prime}$ of the $X$ bra2 transcription start site are sufficient to confer responsiveness both to FGF and, in a concentration-dependent manner, to activin. We present evidence that the suppression of Xbra expression at high concentrations of activin is mediated by paired-type homeobox genes such as goosecoid, Mix.1, and Xotx2.
\end{abstract}

[Key Words: Brachyury; Xenopus; mesoderm induction; activin; FGF; thresholds; homeodomain; goosecoid; Mix.1; Xotx2]

Received June 30, 1997; revised version accepted September 19, 1997.

The mesoderm of Xenopus laevis arises through an inductive interaction in which signals from the vegetal hemisphere of the embryo act on overlying equatorial cells (Sive 1993; Slack 1994). One candidate for an endogenous mesoderm-inducing factor is activin, a member of the TGF $\beta$ superfamily (Asashima et al. 1990; Smith et al. 1990; Thomsen et al. 1990; Dyson and Gurdon 1996). Activin is of particular interest because it induces prospective ectodermal tissue to form different mesodermal cell types in a concentration-dependent manner (Green et al. 1992), and recent evidence suggests that it can function in the embryo as a long-range "morphogen" (Gurdon et al . 1994, 1995; Jones et al. 1996; but see Reilly and Melton 1996).

The dose-dependent effects of activin are illustrated by

Present addresses: ${ }^{1} \mathrm{C}$ entre National de la Recherche Scientifique (CNRS) 1135, Université Pierre et Marie Curie, Biologie Moléculaire et Cellulaire du Developpement, 75005 Paris, France; 'Developmental Genetics Programme, The Krelos Institute, The University of Sheffield, Sheffield S10 2TN, UK.

${ }^{3}$ Corresponding author.

E-MAIL j-im@nimr.mrc.ac.uk; FAX 01819138584. the behavior of Xenopus Brachyury (Xbra). Expression of $\mathrm{Xbra}$ is induced in prospective ectodermal tissue as an immediate-early response to activin and to the mesoderm-inducing factor FGF-2 (Smith et al. 1991). Activation of Xbra in response to activin only occurs, however, in a narrow "window" of activin concentrations: Low doses do not induce expression, intermediate concentrations induce high levels, and yet higher concentrations suppress expression (Green et al. 1992; Gurdon et al. 1994, 1995). Because activin may be able to function as a long-range morphogen, these observations suggest a mechanism by which expression of Xbra might be re stricted to the marginal zone of the Xenopus embryo. Thus, if activin (or an activin-like molecule) is produced in the vegetal hemisphere of the embryo and is able to diffuse from here toward the animal pole, a gradient of activin activity might be established. The concentrations of activin in vegetal and animal regions would, respectively, be too high or too low for expression of Xbra to occur, but the concentration in the equatorial region might be just right.

Analysis of the response of Xbra to different concen- 
trations of activin provides a powerful tool with which to study the interpretation of a morphogen gradient in vertebrate embryos, but analysis of Xbra expression is also of interest because Brachyury is an important regulatory gene in early vertebrate development. In mouse, chick, zebrafish, and Xenopus embryos, Brachyury is expressed at the onset of gastrulation throughout the nascent mesoderm, and transcripts persist thereafter in notochord and in posterior mesoderm (Herrmann et al. 1990; Smith et al. 1991; Schulte-Merker et al. 1992; Kispert et al. 1995b). Loss of Brachyury function in mouse, zebrafish and Xenopus embryos causes loss of posterior mesoderm and impai rment of notochord differentiation (Herrmann et al. 1990; Hal pern et al. 1993; Schulte-Merker et al. 1994; Conlon et al. 1996). Brachyury encodes a nuclear sequence-specific DN A-binding protein that functions as a transcription activator (SchulteMerker et al. 1992; Kispert and Herrmann 1993; Kispert et al. 1995a; Conlon et al. 1996). Widespread expression of Xbra in Xenopus embryos causes ectopic mesoderm formation (Cunliffe and Smith 1992), and the character of the mesoderm formed in such experiments depends on the concentration of Xbra mRNA, the stage at which expression of $\mathrm{Xbra}$ begins, and the genes with which it is coexpressed (Cunliffe and Smith 1992, 1994; O'Reilly et al. 1995; Tada et al. 1997). Thus, Brachyury acts as a genetic switch specifying mesodermal fate in embryonic cells, and normal development of the embryo must depend on precise spatial and temporal control of Brachyury expression.

As a first step toward understanding Xbra transcriptional control, we have isolated the promoter region of Xenopus Brachyury. The gene we have cloned appears to be a pseudoallele of Xbra, and we designate it Xbra2. We describe the structure of the 5 '-flanking region of $\mathrm{Xbra2}$ and demonstrate that the promoter confers mesodermspecific responsiveness to linked reporter genes. A reporter construct containing 381 bp of Xbra2 5'-flanking sequence responds to both fi broblast growth factor (FGF) and activin and, like the endogenous gene, is down-regulated by high concentrations of activin. We provide evidence that this down-regulation is attributable to suppression of transcription by homeobox-containing genes such as goosecoid (Cho et al. 1991) and Mix.1 (Rosa 1989), both of which are induced by high concentrations of activin (Green et al. 1992; Gurdon et al. 1994, 1995, 1996), and by Xotx2 (Pannese et al. 1995). Together, these observations provide the first insights into a "threshold" phenomenon in vertebrate embryos.

\section{Results}

Isolation of genomic clones encoding the $5^{\prime}$ end of Xenopus Brachyury

Genomic clones containing the first exon of Xenopus Brachyury were obtained as described in $M$ aterials and Methods. Clone $3 \mathrm{~A} 1$ contained $\sim 2.2 \mathrm{~kb}$ of DN A 5' to the probable translation initiation codon, and comparison with Xbra cDNA revealed that the exon 1/intron 1 boundary is located at codon 67 (Fig. 1). There were significant differences in nucleoti de sequence between $3 \mathrm{~A} 1$ and the original Xbra cDN A (Smith et al. 1991), al though

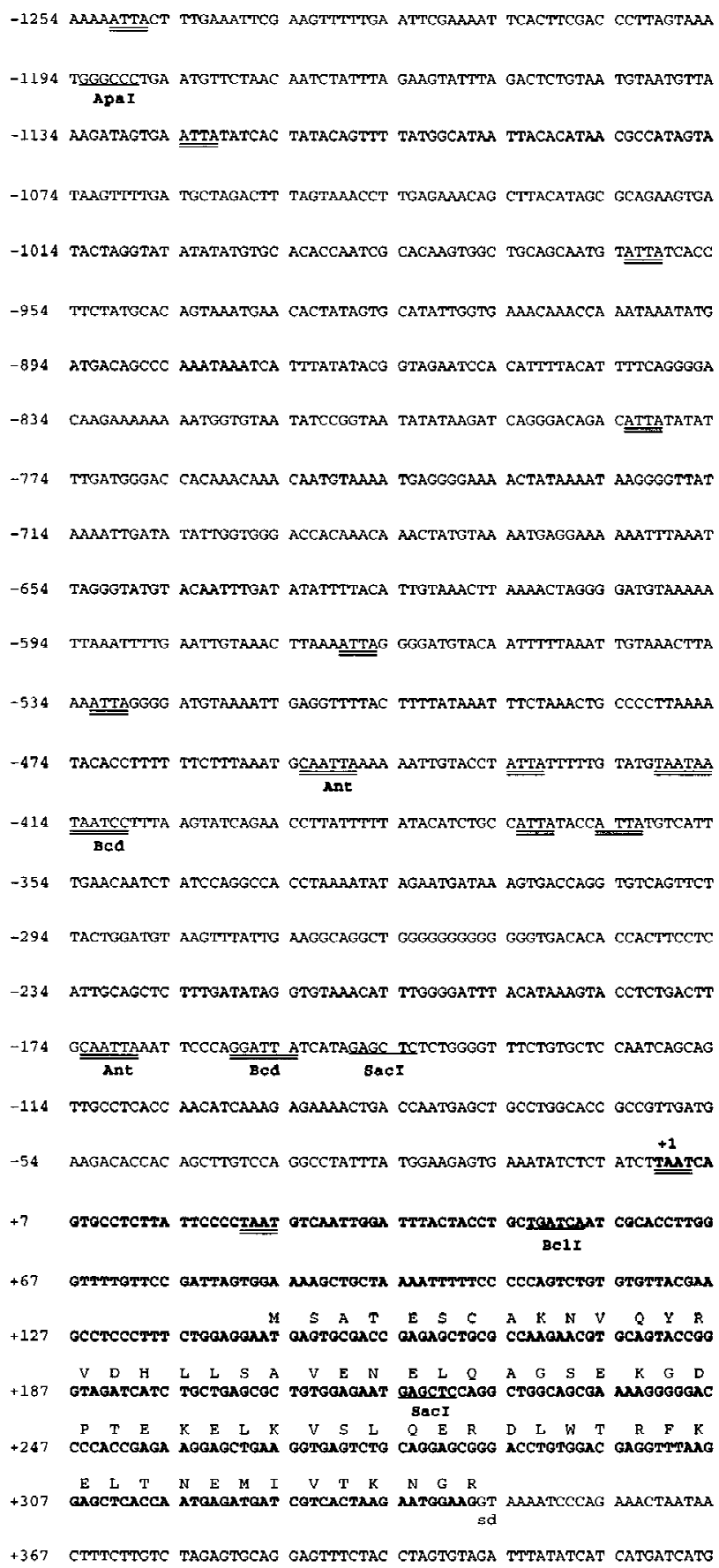

Figure 1. Sequence of exon 1 of Xbra2 (bol dface type) together with $1.2 \mathrm{~kb}$ of $5^{\prime}$-flanking sequence. The first 82 bases of intron 1 are al so included. Transcription initiation site is indicated by +1 and is also the first nucleotide in boldface type. ATTA sequences are double-underlined, and Antennapedia- and Bicoidspecific sites are marked Ant and Bcd, respectively. This sequence has been submitted to the EMBL database, accession number AJ001528. 
they are $99 \%$ identical at the amino acid level over the first 67 amino acids. This suggests that $3 A 1$ is derived from a second Xenopus Brachyury gene, which we designate Xbra2. Consistent with this suggestion, the spatial and temporal expression patterns of $\mathrm{Xbra2}$ proved to be indistinguishable from those of Xbra and different from other Xenopus T-box-containing genes (data not shown; see Lustig et al. 1996; Ryan et al. 1996; Stennard et al. 1996; Zhang and King 1996). Furthermore, Xbra2 expression, like that of Xbra, is induced in animal caps by FGF-2 and activin (data not shown).

DNA $(2.1 \mathrm{~kb})$ immediately upstream of the Xbra2 promoter drives mesoderm-specific gene expression in Xenopus embryos

TheXbra2 transcription initiation site was defined using primer extension and is located 144 nucleotides upstream of the initiator methionine codon (data not shown). As a first step in the analysis of Xbra2 regulation, $2.1 \mathrm{~kb}$ of Xbra2 5'-flanking sequence and $\sim 50 \mathrm{bp}$ of 5 -untranslated regi on were subcloned into the luciferase reporter plasmid pGL2, thus generating Xbra2.pGL2. This construct (or the promoterless vector pGL2Basic) was coinjected with the internal control pSV. $\beta$-galactosidase into blastomeres of tier $A$ or tier $C$ of Xenopus embryos at the 32-cell stage. These give rise predominantly to the ectoderm or the mesoderm of the embryo, respectively (Dale and Slack 1987). Injected embryos were assayed for luciferase and $\beta$-galactosi dase activities at gastrula stage 12 . The ratio of Iuciferase to $\beta$-galactosidase activity provides a normalized measure of luciferase expression. Figure 2A shows that al though injection of the Xbra2 reporter into tier $A$ results in low luciferase activity, extracts of tier $\mathrm{C}$-injected embryos showed high levels. No significant luciferase activity was observed after injection of the promoterless plasmid pGL2Basic. M easurement of luciferase activity at different stages of development (Fig. 2B) showed that reporter gene activity increased dramatically from the mid-blastula stage to the neurula stage. This suggests that sequences within $2.1 \mathrm{~kb}$ of 5'-flanking region confer mesoderm-specific and temporally correct transcriptional activity to Xbra2.

To monitor transcripts origi nating from the Xbra2 promoter directly, we constructed Xbra2. $3 g$, in which 2.1 $\mathrm{kb}$ of $\mathrm{Xbra2} 5^{\prime}$-flanking region was placed upstream of the human $\beta$-globin gene, and anal yzed levels of $\beta$-gl obin mRN A by RN ase protection. Figure $2 B$ (inset) shows that injection of this construct into tier A elicits only weak synthesis of correctly processed transcript, whereas injection into tier $C$ causes strong activation.

The ability of sequences within $2.1 \mathrm{~kb}$ of Xbra2 5'flanking region to drive mesoderm-specific expression was then examined using the construct Xbra2.GFP, in which green fluorescent protein (GFP) (Zernicka-Goetz et al. 1996) was used as a reporter. Xenopus embryos at the four-cell stage were injected in each bl astomere with a total of $100 \mathrm{pg}$ of reporter DN A, and GFP activity was visual ized by direct observation (not shown) foll owed by in situ hybridization using a GFP probe. Mosaic GFP
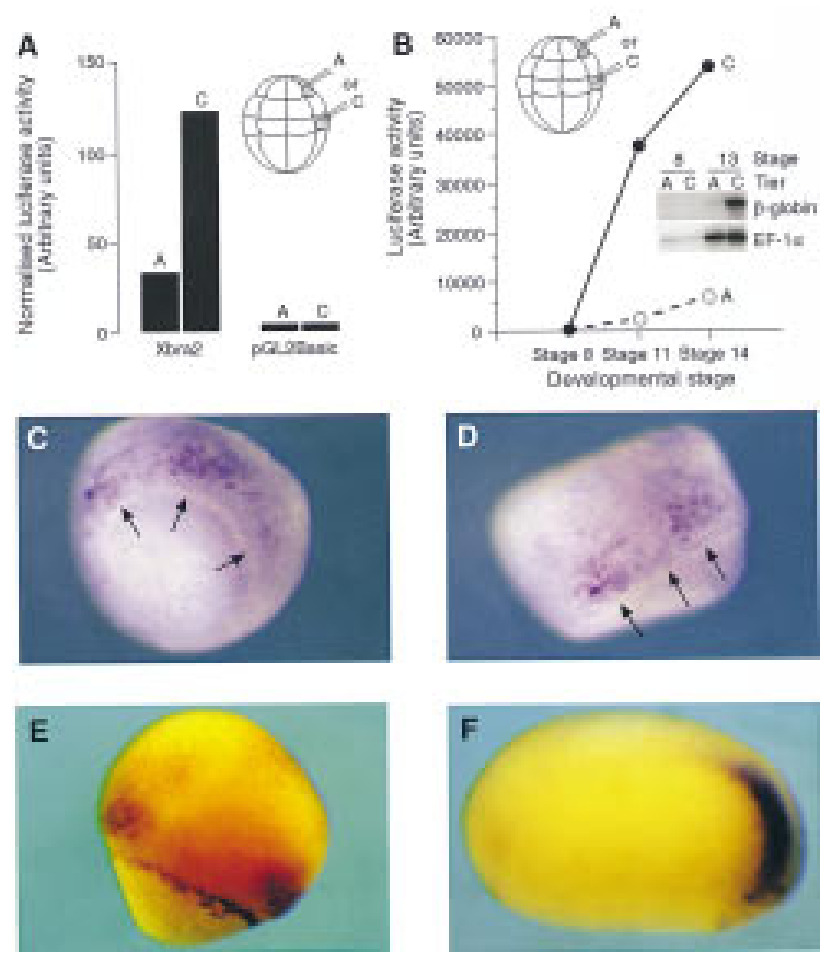

Figure 2. Mesoderm-specific expression of reporter gene constructs containing $2.1 \mathrm{~kb}$ of Xbra2 $5^{\prime}$-flanking sequence. (A) Xbra2.pGL2 or the promoterless plasmid pGL2Basic was coinjected with pSV. $\beta$-galactosidase into a single blastomere of either tier A (prospective ectoderm) or tier C (prospective mesoderm) of 32-cell stage embryos (see inset). Embryos were collected for luciferase and $\beta$-gal actosi dase activity assays at stage 12.5. (B) Luciferase activity in extracts of embryos at stage 8,11 , or 14 injected with Xbra2.pGL2 into a single blastomere of either tier A or tier $\mathrm{C}$ at the 32-cell stage. (Inset) RN ase protection assay for expression of Xbra2.ßg in embryos injected into a single blastomere of tier $\mathrm{A}$ or tier $\mathrm{C}$ and collected for assay at stage 8 or stage 13 . EF- $1 \alpha$ was used as a loading control. This experiment has been performed four times, with similar results each time. (C,D) Xbra2.GFP was injected equatorially into all four blastomeres of four-cell stage embryos, and distribution of GFP transcripts at stage 10.5 was determined by whole-mount in situ hybridization. Arrows point to the blastopore lip. $(E, F)$ Xbra2.GFP was used to generate transgenic embryos that were analyzed as in $C$ and $D$ at gastrula $(E)$ or tail bud ( $F$; anterior to the left) stage.

expression was seen in prospective mesodermal cells at stage 10.5 (Fig. 2C,D). This expression pattern was specific to Xbra2 flanking sequence, because the promoter of the ubiquitously expressed and constitutively active EF- $1 \alpha$ directed widespread mosaic expression (not shown).

To overcome problems associated with mosaic inheritance of injected DNA and to test the ability of the Xbra2 promoter to drive mesoderm-specific expression when integrated into chromatin, we generated transgenic embryos carrying Xbra2.GFP (Fig. 2E,F). At the gastrula stage, most transgenic embryos showed expression of GFP mRNA in a ring around the blastopore, as is seen 
with the endogenous gene. However, the reporter gene differed from the endogenous gene because the ring was discontinuous, with a gap on the dorsal side (Fig. 2E). This observation is consistent with experiments using the mouse Brachyury promoter, where there are separate elements for primitive streak and notochord expression (Clements et al. 1996). At the tail lbud stage, GFP mRN A was normally found in the posterior mesoderm, coincident with endogenous Xbra expression (Fig. 2F); there is no expression of Xbra RN A in the notochord at this stage (Green et al. 1997). Together, these results show that 2.1 kb of Xbra2 5' sequence is sufficient to direct expression to a large subset of sites where the endogenous gene is expressed; sequences located el sewhere are required for expression in the presumptive notochord.

Sequence within 381 bp of the transcription start site is sufficient to elicit responses to FGF and activin

We then tested the ability of FGF, of members of the MAP kinase pathway, and of activin to activate Xbra2.pGL2. The reporter construct was coinjected with a reference plasmid into Xenopus embryos at the onecell stage. Animal caps were dissected at blastula stages and were incubated in medium containing FGF or activin or were left untreated. Some embryos were also injected with RNA encoding v-Ras or a constitutively active form of MEK1, MEK $1^{\text {S217E/S221E }}$ (Umbhauer et al. 1995). Reporter gene activities were analyzed in animal cap extracts at gastrula stage 12.5. FGF caused a strong induction of luciferase activity in animal caps injected with Xbra2.pGL2 (Figs. 3 and 4A,B). In animal caps expressing v-ras or MEK1 ${ }^{\mathrm{S} 217 \mathrm{E} / \mathrm{S} 221 \mathrm{E}}$, the Xbra2.pGL2 construct was activated in the absence of FGF (Fig. 4A). N either FGF nor $v$-Ras caused activation of the promoterless vector pGL2Basic (data not shown). These results sug- gest that el ements mediating FGF-dependent gene activity are located within $2.1 \mathrm{~kb}$ of upstream flanking sequence.

Activin treatment of animal caps al so caused expression of the Xbra2.pGL2 reporter construct. These experiments gave variable results, however, and it seemed possible that this was attributable to cells within the animal caps experiencing different concentrations of activin; expression of the endogenous $X$ bra gene is very sensitive to activin concentration (Green et al. 1992; Gurdon et al. 1994, 1995). In an effort to obtain a more uniform distribution of activin, activin RNA was coinjected with the Xbra2.pGL2 reporter construct and a reference plasmid into the animal hemispheres of Xenopus embryos at the one-cell stage (see Gurdon et al. 1994). When low levels of RN A were injected, strong activation of reporter gene activity was observed (Figs. 3 and 4B).

To identify elements in the Xbra2 promoter responsible for mediating the response to FGF and activin, a deletion series of Xbra2.pGL2 was generated, and constructs were tested for their ability to respond to inducing factors. The degree of induction varied from experiment to experiment, perhaps owing, among other factors, to mosaic expression of the reporter construct (see Discussion). N evertheless, removal of $5^{\prime}$ sequences down to -381 bp did not prevent induction by FGF and activin, whereas 231 bp was unable to eli cit a significant response (Fig. 3).

Examination of Figure 3 suggests that levels of reporter geneactivation in response to FGF and activin arehigher in constructs containing 2.1 and $1.0 \mathrm{~kb}$ of flanking sequence than in those containing only $381 \mathrm{bp}$. However, the variation in levels of induction observed in different experiments made it difficult to study this issue in a quantitative manner, and the variation also complicated the precise localization of activin or FGF response elements.

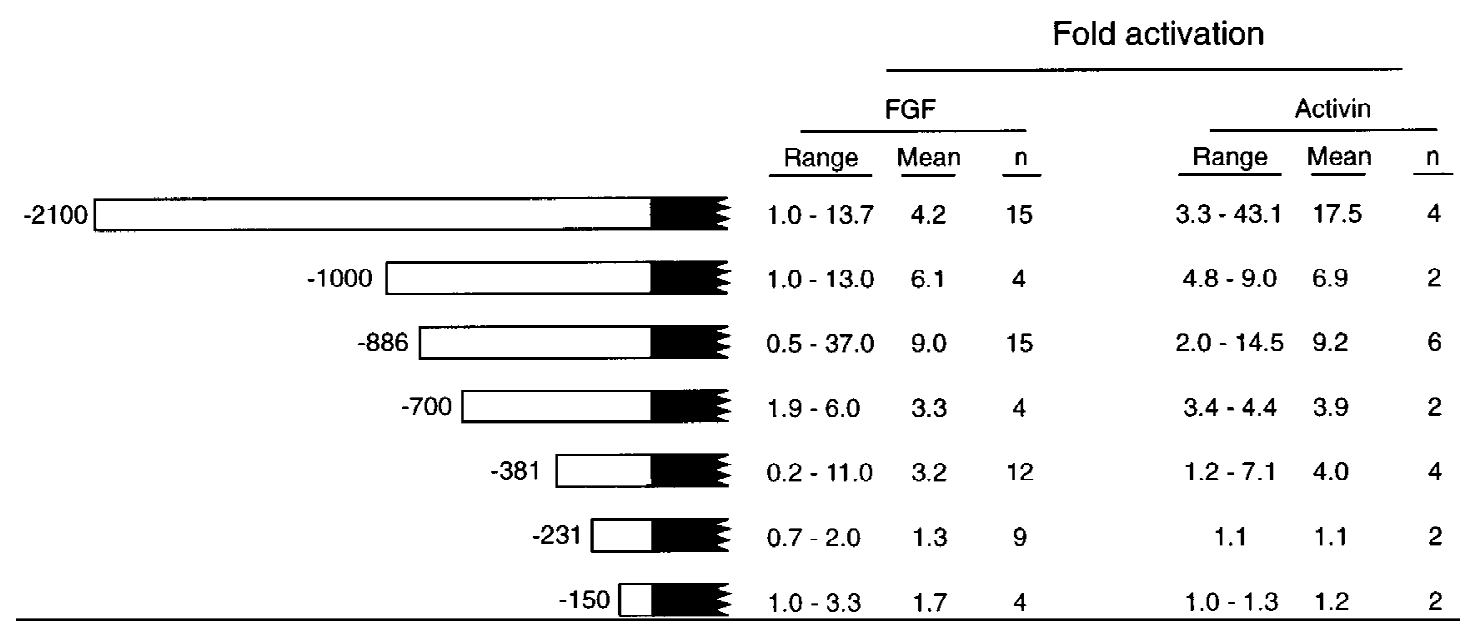

Figure 3. FGF and activin activate expression of a reporter gene construct containing $2.1 \mathrm{~kb}$ of Xbra2 $5^{\prime}$-flanking sequence. Sequences upstream of -381 in the Xbra2 5' -flanking sequence are dispensable for response of Xbra2 to FGF ( $25 \mathrm{ng} / \mathrm{ml})$ and activin. Embryos were injected with the indicated constructs and reference plasmid and, in some cases, with $1 \mathrm{pg}$ of activin mRN A, as described in M aterials and $\mathrm{M}$ ethods. $\mathrm{N}$ ormal ized firefly luciferase activity from stage 12.5 caps is expressed as fold activation over untreated caps. (n) $\mathrm{N}$ umber of experiments. 


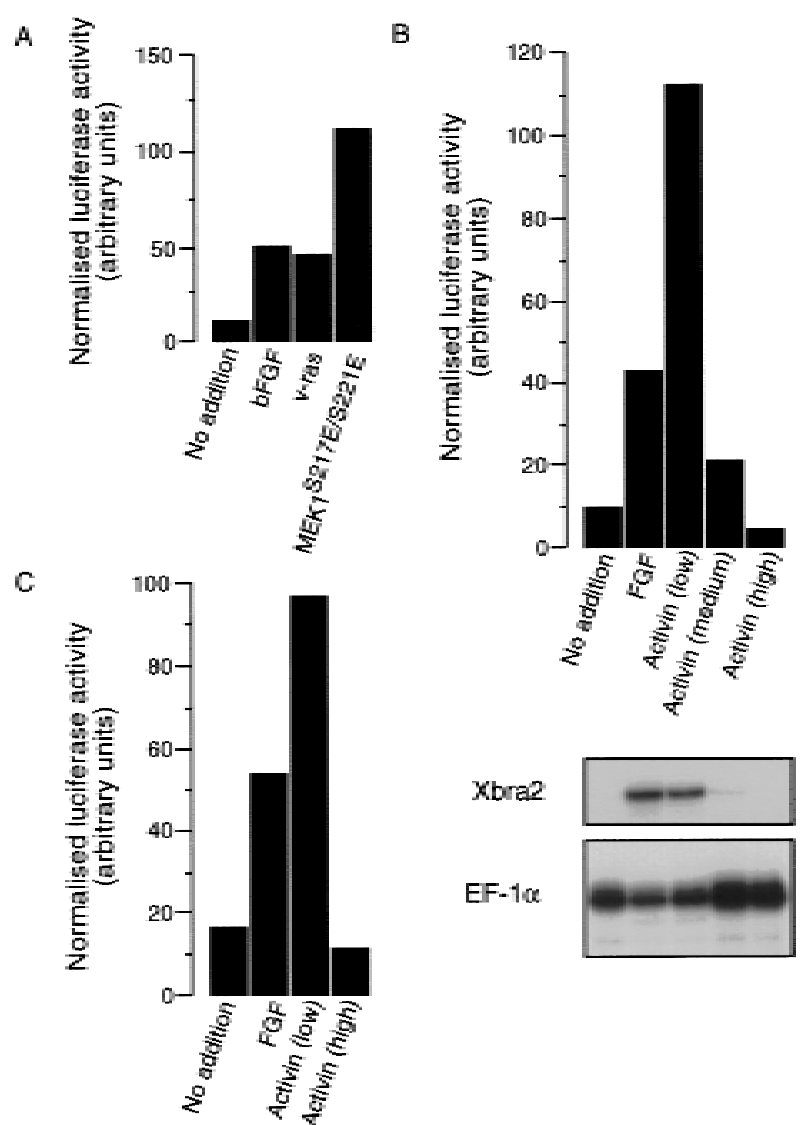

Figure 4. Activation by FGF and components of the MAP kinase pathway of a reporter gene construct containing $2.1 \mathrm{~kb}$ of Xbra2 5'-flanking sequence. Activation of the same reporter in response to activin, and of a reporter containing 381 bp of flanking sequence, is dose dependent. (A) N ormalized luciferase activity in animal caps injected with Xbra2.pGL2. One group of caps was also injected with v-Ras mRNA, a second with

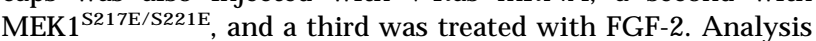
was performed at control stage 12.5. This experiment has been performed 3 times with $M E K 1^{\mathrm{S} 217 \mathrm{E} / \mathrm{S} 221 \mathrm{E}}$ al one, 10 times with V-Ras alone, and once with MEK $1^{\mathrm{S} 217 \mathrm{E} / \mathrm{S} 221 \mathrm{E}}$ and V-Ras in the same experiment. Similar results were obtained each time. (B) Normalized luciferase activity in animal caps treated with FGF-2 or injected with different amounts of activin mRNA (in this experiment "low" represents 1 pg, "medium" represents 5 pg, and "high" represents $50 \mathrm{pg}$ ). A nalysis was at control stage 12.5. Half of each group of caps was assayed for luciferase and $\beta$-galactosidase activities, and the other half was assayed for expression of endogenous Xbra2 by RN ase protection. Note that high levels of activin suppress expression of both endogenous Xbra2 and the reporter construct. This experiment has been performed out three times, with similar results each time. (C) A similar experiment to that in B using $-381 X$ bra2.pGL2 (in this experiment "low" represents 1 pg and "high" represents 100 pg activin RNA).

The 5'-flanking region of the Xbra2 gene confers dose-dependent responsiveness to activin

The observation that efficient induction of Xbra2.pGL2 is elicited only by low concentrations of activin was reminiscent of the response of the endogenous gene, and this inspired us to examine the phenomenon in detail. Therefore, different amounts of activin RNA were coinjected with the Xbra2.pGL2 reporter construct and a reference plasmid into Xenopus embryos, animal caps were dissected at stage 8 , and levels of reporter and of endogenous Xbra2 expression were determined at stage 12.5. Injection of low levels of activin mRN A (1 pg in Fig. 4B) strongly activated Xbra2.pGL2 in animal cap explants, whereas injection of intermediate levels (5 pg) gave much lower activation, and a high concentration $(50 \mathrm{pg})$ reduced luciferase activity to bel ow basel ine levels. This doseresponse profile mirrored endogenous Xbra2 expression (Fig. 4B). These results show that $2.1 \mathrm{~kb}$ of Xbra2 5'-flanking sequence contains el ements mediating a dose-dependent response to activin. Further experiments revealed that similar results could be obtained with only 381 bp of Xbra2 flanking sequence (Fig. 4C).

Suppression of Brachyury expression by homeobox-containing genes

High levels of activin cause Xbra2.pGL2 activity to fall to a level below that observed in the absence of activin (Fig. 4B,C), suggesting that Xbra transcription is suppressed actively. Previous work, in which the concentration-dependent induction of Xbra and other genes was studied at different times after activin treatment, identifies two candidate repressors as goosecoid and Mix.1 (Green et al. 1994; see also Artinger et al. 1997). When assayed shortly after activin treatment, levels of Xbra change little as the concentration of activin is raised, whereas expression of both goosecoid and Mix.1 increases dramatically. These genes might therefore be responsible for the subsequent down-regulation of Xbra that occurs at high levels of activin. Additional circumstantial evidence suggesting that goosecoid and Mix.1 may regulate Xbra expression includes the observations that goosecoid functions as a transcriptional repressor (Goriely et al. 1996; Smith and Jaynes 1996) and that under certain circumstances the two proteins can bind DN A cooperatively (Wilson et al. 1993). Goosecoid and Mix.1 both encode paired class homeodomains (Rosa 1989; Blumberg et al. 1991), and another member of this family that is also expressed in the early Xenopus embryo is Xotx2 (Blitz and Cho 1995; Pannese et al. 1995).

To examine whether goosecoid, Mix.1, or Xotx2 might cause down-regulation of Xbra, Xenopus embryos were injected at the four-cell stage with RNA encoding these proteins, and expression of Xbra and Xbra2 was examined by in situ hybridization at the early gastrula stage. All three gene products caused down-regulation of Xbra expression (see Fig. 5A,B for examples of down-regulation with goosecoid and $X o t \times 2$ ), whereas injection of RNA encoding a mutant version of Xot $\times 2$, in which the lysine at position 9 of the recognition helix of the homeodomain is replaced by glutamic acid (Xotx2 $\mathrm{K} \rightarrow \mathrm{E}$ ), had no effect (Fig. 5C).

Suppression of Xbra2 expression by goosecoid, M ix.1, and Xotx2 was also revealed in experiments in which 

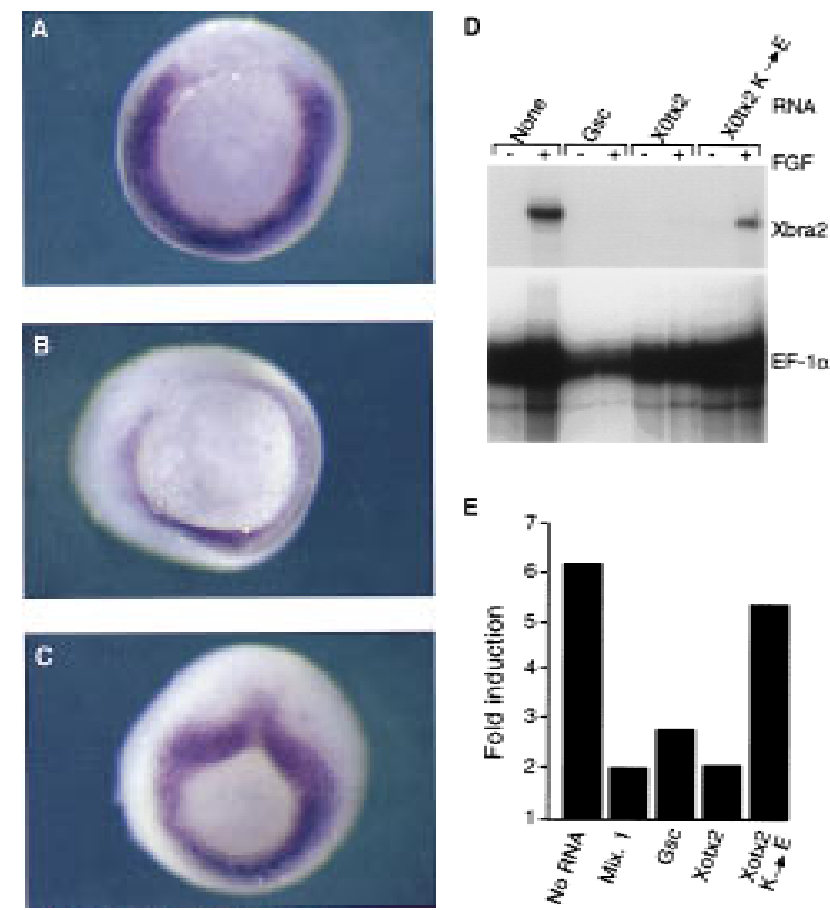

Figure 5. Suppression of Xbra expression in gastrula-stage embryos by paired-type homeodomain proteins. Embryos at the four-cell stage were injected equatorially with $500 \mathrm{pg}$ of goosecoid (A), Xotx2 (B), or Xotx $2 \mathrm{~K} \rightarrow \mathrm{E}(\mathrm{C}) \mathrm{RN} \mathrm{A}$ in one blastomere, and the expression pattern of Xbra was analyzed by wholemount in situ hybridization at the early gastrula stage. $N$ ote lack of Xbra expression in part of the equatorial region of embryos in A and B. All embryos shown are from the same experiment; that in $\mathrm{C}$ is at a slightly later stage than those in A and B. (D) Suppression of FGF-induced Xbra2 mRN A in animal caps by goosecoid, Mix.1, and Xotx2 but not by Xotx $2 \mathrm{~K} \rightarrow \mathrm{E}$. Embryos at the one-cell stage were injected with $1 \mathrm{ng}$ of the indicated RN As, and animal caps were cut at stage 8 and incubated in FGF until stage 12 . Xbra2 and EF-1 $\alpha$ transcripts were detected by RN ase protection. N ote that FGF-induced expression of Xbra2 is strongly inhibited by goosecoid, Mix.1, and Xotx2 but not by Xotx2 K $\rightarrow$ E. (E) Suppression of FGF-induced Xbra2.pGL2 luciferase activity in animal caps by goosecoid, Mix.1, and Xotx2 but not by Xotx $2 \mathrm{~K} \rightarrow \mathrm{E}$. Embryos were coinjected with $1 \mathrm{ng}$ of the indicated RN As, $30 \mathrm{pg}$ of Xbra2.pGL2, and $10 \mathrm{pg}$ of pRL-SV reference plasmid. Animal caps were excised at stage 8 and incubated with FGF until stage 12.5, and firefly and Renilla luciferase activities were determined. Activity of Xbra2.pGL2 is presented as fold activation over uninduced levels. This experiment was repeated twice for all four RN As and four additional times with goosecoid, with similar results.

animal pole explants derived from injected embryos were treated with FGF. Expression of Xbra2 in response to FGF was strongly down-regulated by all three proteins but not by the control construct Xotx2 K $\rightarrow \mathrm{E}$ (Fig. 5D); similar results were seen when activin was used instead of FGF (not shown). The effects of goosecoid, Mix.1, and Xotx2 were specific, because activation of Pintallavis (Ruiz i Altaba and Jessell 1992) was not affected (not shown).
We then studied the ability of goosecoid, Mix.1, and Xotx2 to suppress FGF-induced activity of the Xbra2.pGL2 reporter in animal pole explants. The presence of all three gene products caused a general reduction in Xbra2.pGL2 reporter activity in such caps (not shown), and as illustrated in Figure 5E, overexpression of goosecoid, Mix.1, and Xotx2, but not of Xotx2 K $\rightarrow E$, caused a reduction in FGF-induced reporter activity, suggesting that these transcription factors modulate Xbra2 expression by suppressing its transcriptional activity. Similar results were seen when animal pole explants were treated with activin (not shown).

Goosecoid, Xotx2, and Mix.1 bind to sequences within the $5^{\prime}$-flanking region of $\mathrm{Xbra2}$

The suppression of Xbra2 transcription by goosecoid, Mix.1, and Xotx2 may occur indirectly through activation of downstream repressors or directly, by binding to sites in the Xbra2 regulatory region. Most homeodomain-containing proteins bind to sequences contai ning a TAAT core (Treisman et al. 1992), and there are four such motifs within the 381 bp of Xbra2 flanking sequence that confers suppression of reporter gene expression in response to high levels of activin (Fig. 1). One of these motifs, GGATTA, matches the consensus binding site of the Drosophila morphogen Bicoid, to which goosecoid al so binds (Blumberg et al. 1991; Wilson et al. 1993). Recognition of the GG dinucleotide $5^{\prime}$ of the ATTA motif is specified by lysine at position 50 of the homeodomain, a residue also present in Otx2. A nother site present in the Xbra2 5 '-flanking regi on, CAATTAA, conforms to the consensus for the Antennapedia class of homeobox proteins, which have gl utamine at position 50 of the homeodomain (Desplan et al. 1988; Hanes and Brent 1991): M ix.1 belongs to this class.

Goosecoid, Xotx2, and Mix.1 proteins were prepared by in vitro translation and tested for the ability to bind to the Bicoid and A ntennapedia sites in the Xbra2 $5^{\prime}$-flanking region (nucl eotides -174 to -152 ). Both goosecoid and Xotx2 bind the $-174 /-152$ probe specifically (Fig. 6). As expected, no specific binding was observed with Xotx2 $\mathrm{K} \rightarrow \mathrm{E}$ (Fig. 6). Mix.1 also forms a complex with the $-174 /-152$ probe, but this is rather weak, perhaps reflecting a lower affinity for the site; Wilson et al. (1993) have also observed that Mix.1 binds only weakly to a single site.

Goosecoid acts on the -381 Xbra2 promoter through Antennapedia and Bicoid sites

To investigate whether the Antennapedia and Bicoid binding sites identified in the $-174 /-152$ region are involved in suppression of Xbra2 expression, we have mutated them in the background of the -381Xbra2 construct, the shortest promoter fragment that is inducible by FGF and low concentrations of activin. This construct was chosen over larger ones because it has only two sites predicted to bind pai red-type homeodomain proteins. To further simplify analysis, we have concentrated on 


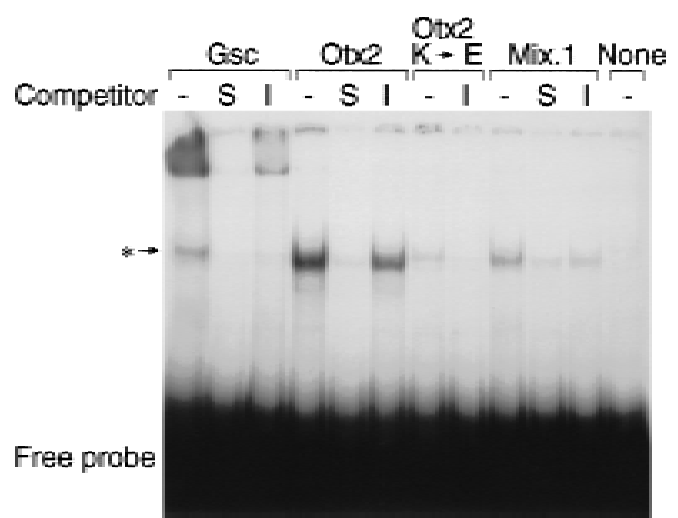

Figure 6. goosecoid, $X$ otx2, and Mix.1 bind to the $-174 /-152$ region of the Xbra2 promoter. goosecoid, Xotx2, and Mix.1 were translated in a coupled transcription-translation system; the DNA template used in each reaction is indicated above the brackets. In some cases, binding reactions were preincubated with a 200-fold molar excess of specific competitor (unlabeled $-174 /-152$ ol igonucleotide, S) or with a 200 -fold molar excess of irrelevant competitor (unlabeled $-43 /-19$ oligonucleotide, I). Complexes were resolved on a $4 \%$ polyacrylamide gel. The asterisk (*) indicates the position of a nonspecific DN A-binding complex; this complex varied between lanes and between different experiments.

goosecoid as a representative paired-type homeodomain protein, and to compare directly the activities of wildtype and mutant constructs, we have coinjected them into the same embryos, with the wild-type construct driving expression of Renilla luciferase and the mutant construct driving firefly luciferase.

Figure 7A shows that activin-induced reporter activity is suppressed by goosecoid in the wild-type reporter construct but not in the mutant construct in which the Antennapedia and Bicoid binding sites are destroyed (Fig. 7C). Induction of the mutant construct by low levels of activin in these experiments appears to be weaker than induction of the wild-type construct (Fig. 7A).

To investigate whether goosecoid is also able to suppress Xbra2 promoter activity in a heterol ogous system, we have used transi ent transfections of $\mathrm{NIH}-3 \mathrm{~T} 3$ mouse embryo fibroblasts. The activity of $-381 \mathrm{Xbra2}$.luciferase reporter is very low in these cells and could not be used reliably as a baseline for studies of suppression. We therefore tested the Antennapedia and Bicoid sites by cloning the $-381 /-150$ region of $\mathrm{Xbra2}$ upstream of the SV40 minimal promoter. Figure 7B shows that goosecoid suppresses activity of the wild-type $-381 /-150 . S V 40$ reporter but not that of the mutant version. Additional experiments indicate that mutation of the Bicoid site alone is sufficient to abolish the effect of goosecoid, as expected from its binding site preference (not shown).

\section{Discussion}

In this paper we demonstrate that sequences within 381 bp of the Xbra2 transcription initiation site confer FGF- and activin-mediated gene activation in animal cap explants. The response of reporter constructs to activin, like the response of the endogenous gene, is concentration dependent, thus offering an opportunity to study a threshold phenomenon in a vertebrate embryo. Our re sults suggest that the down-regulation of Xbra2 expression in response to high concentrations of activin is attributable to suppression by homeodomain-containing proteins such as goosecoid, Xotx2, and M ix.1.

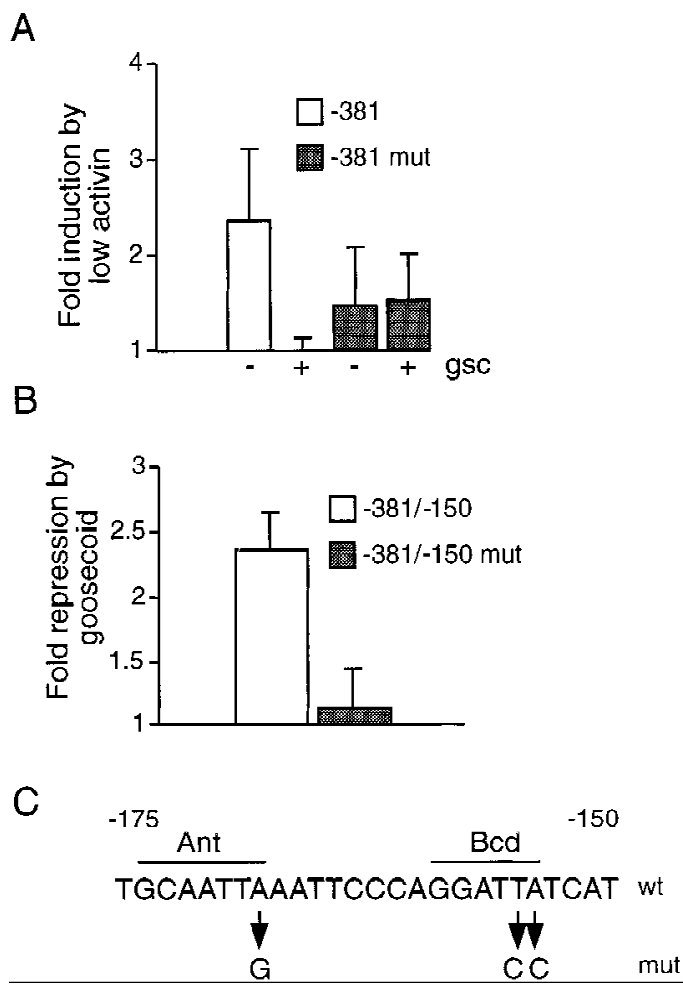

Figure 7. Suppression of $-381 \mathrm{Xbra2.luciferase}$ activity by goosecoid requires Antennapedia and Bicoid homeodomainbinding sites. (A) Embryos were injected with 15 pg mutated -381 Xbra2.firefly luciferase (see C), 15 pg -381Xbra2.Renilla luciferase, and $30 \mathrm{pg}$ pEF-1 $\alpha$. $\beta$-galactosidase; in addition to this combination of DN As, some embryos were injected with $1 \mathrm{pg}$ of activin mRNA or with a mixture of $1 \mathrm{pg}$ of activin mRNA and 1 ng of goosecoid mRN A. A nimal caps were excised at the blastula stage and incubated until stage 12.5 , when firefly and Renilla luciferase and $\beta$-galactosi dase activities were determined. The graph shows fold induction by activin in the presence or absence of goosecoid, as obtained with the wild-type and mutated reporters. $\mathrm{N}$ ormalized luciferase activities from four independent experiments were used in this figure. Bars show S.D.S. (B) N IH-3T 3 cells were cotransfected in duplicate with a combination of CMV overexpression vector (either empty or goosecoid expressing), wild-type or mutated Xbra2/SV40 reporter, and reference plasmid. Luciferase activities were determined, and the results are expressed as the fold repression of reporter activity by goosecoid for each construct. Data from four experiments was used for this graph. Bars show S.D.S. (C) Sequence of the wild-type and the mutant Antennapedia and Bicoid sites. 
Expression of Xbra2 and sequence of the Xbra2 promoter

The existence of two Brachyury genes, Xbra and Xbra2, is consistent with the pseudotetraploid nature of the Xenopus laevis genome (Kobel and Du Pasquier 1986). The regulation of Xbra2 is similar to that of Xbra (Smith et al. 1991), suggesting that they play similar roles in mesodermal differentiation.

Inspection of the sequence of the Xbra2 promoter region reveals, in addition to potential binding sites for homeodomain-containing proteins, the presence of three sites similar to the half-palindrome binding site for $\mathrm{X}$ bra protein (AGGTGT or the complementary ACACCT) at positions -473 to $-468,-307$ to -302 , and -217 to -211 (Kispert and Herrmann 1993). Such sequences would normally be predicted to occur only once every 2048 bp; so the clustering of three within 262 bp may be of significance. Because Xbra can activate its own transcription (Rao 1994), it will be of interest to determine whether Xbra can bind to these sequences in vitro and whether mutations in them impair autoregulation. Recent experiments suggest, however, that Xbra activates its own transcription indirectly (Tada et al. 1997).

The Xbra2 promoter sequence bears no homology to the regulatory region of its mouse homolog, Brachyury $(T)$, even though the mouse sequence is sufficient to direct expression in the primitive streak (Clements et al. 1996). It is possible that homologous sequences are located at nonconserved sites or that different mechanisms regulate the expression of these orthologs. Because regulatory elements are conserved frequently between orthologs (Nonchev et al. 1996), it will be of interest to understand this apparent difference in the mechanism of regulation between Xbra and $\mathrm{T}$, as it may shed light on the evolution of regulatory pathways. There is al so little similarity between the Xbra2 promoter sequence and that of Ciona intestinalis Brachyury (Corbo et al. 1997), although we note that a putative Suppressor of hairless site (TTCCCAGG), which may play a role in regulation of Ciona intestinal is Brachyury expression (Corbo et al. 1997), is present between nucleotides -165 and -158 .

It is also noteworthy that the activin-responsive regions of the Xenopus genes goosecoid (Watabe et al. 1995), Mix.2 (Huang et al. 1995; Vize 1996), and XFD-1' (Kaufmann et al. 1996) are dissimilar and that none shows significant homology to the Xbra2 promoter. These results suggest that there are multiple activin-responsive transcription factors, rather than a single dedicated factor that is shared by all activin-inducible immediate-early genes.

$\mathrm{Xbra2}$ promoter sequences up to $-2.1 \mathrm{~kb}$ respond to endogenous mesoderm-inducing signals

Xbra2 5'-flanking sequence $(2.1 \mathrm{~kb})$ drives mesodermspecific expression of reporter constructs in Xenopus embryos. Lack of reporter gene expression in the dorsal marginal zone (Fig. 2E) indicates, as in the mouse embryo (Clements et al. 1996), that additional Xbra promoter elements are required for notochord expression.
Sequences within -381 bp of the Xbra2 transcription start site respond to both FGF and activin

Experiments using animal cap tissue revealed that $2.1 \mathrm{~kb}$ of Xbra2 5'-flanking sequence is sufficient to confer responsiveness to FGF, to components of the FGF signal transduction pathway, and to activin. Our attempts to map precisely FGF- and activin-response el ements were thwarted, however, by variability from experiment to experiment. This variability is likely to be owing to several factors, including mosaic expression of the reporter construct (Vize et al. 1991), heterogeneity of different embryo batches, and perhaps the absence of some elements required for full activity of the Xbra2 promoter. It may also be that distinct elements are required for activation and for subsequent maintenance of Xbra2 expression (not shown; see also Clements et al. 1996). We are currently testing the effects of additional Xbra2 genomic sequences; preliminary results show that adding $2 \mathrm{~kb}$ of Xbra2 sequence downstream of +54 has no effect on the inducibility of the $-2.1 \mathrm{~kb}$ promoter by activin. N evertheless, our data (Fig. 3) allow us to conclude that elements that respond to FGF and activin reside between -381 bp and -231 bp of the Xbra2 transcription start site. The response of the -381-bp construct is weaker than that of the larger -1.0 - or $-2.1-\mathrm{kb}$ reporter constructs (Fig. 3), suggesting that el ements between -1000 and -381 are required for enhancement of the transcriptional re sponse.

Dose-dependent effects of activin on activation of the Xbra2 promoter sequences

Although identification of activin- and FGF-responsive elements in the Xbra2 promoter has proved trouble some, we observe consistently that whereas low concentrations of activin elevate expression of a reporter gene driven by the Xbra2 promoter, high concentrations cause a strong down-regulation. In this respect, the Xbra2 reporter construct resembles the endogenous Xbra gene (Green et al. 1992, 1994; Gurdon et al. 1994, 1995; Jones et al. 1996), and the behavior of the reporter construct offers an opportunity to investigate the mechanism by which Xbra expression is activated only in a narrow window of activin concentrations. This phenomenon may be important in ensuring that Xbra and Xbra2 are expressed in the right regions of the embryo. For example, levels of activin, or an activin-related molecule such as Vgl (Weeks and M elton 1987), might be too high in the vegetal hemisphere of the late blastula/ early gastrula to allow expression of Xbra and too low in the animal hemisphere; only in the marginal zone might the concentration be appropriate (Gurdon et al . 1994, 1995; Jones et al. 1996).

Suppression of Xbra2 expression by goosecoid, Mix.1, and $\mathrm{Xot} x 2$

High concentrations of activin cause the expression of Xbra2 reporter constructs to fall bel ow baseline levels, 
implying active suppression of Xbra2 expression. This might occur through the induction, by high concentrations of activin, of gene products that suppress expression of Xbra2. As discussed in Results, two candidate Xbra2 repressors are goosecoid and Mix.1, both of which are induced by high levels of activin (Green et al. 1992, 1994; Gurdon et al. 1994, 1995, 1996). goosecoid and Mix.1 both encode paired class homeodomains (Rosa 1989; Blumberg et al. 1991), and another member of this family is Xotx2, which is al so expressed in the marginal zone of the early Xenopus embryo and may be a target of goosecoid regulation (Blitz and Cho 1995; Pannese et al. 1995). Our experiments show that overexpression of all three homeobox-contai ning genes leads to suppression of Xbra2, both in whole embryos and in the animal cap mesoderm induction assay. This suppression can occur at the level of transcriptional regulation, because a simiIar effect is observed using Xbra2 reporter constructs. Suppression of Xbra expression by goosecoid has also been reported by Artinger et al. (1997).

In our attempts to understand the roles of homeoboxcontaining genes in the suppression of Xbra expression, we have focused on goosecoid and on a $-174 /-152$ promoter fragment that contains Antennapedia and Bicoid binding sites to which goosecoid, M ix.1, and Xotx2 bind (Fig. 6; see also Artinger et al. 1997). M utating these sites in a $-381 X$ bra2 reporter construct abol ishes suppression of activin-induced activity by goosecoid (Fig. 7A). Similarly, the integrity of these sites is necessary for repression by goosecoid of the activity of a heterologous promoter fusion carrying a $-381 /-150$ fragment in $\mathrm{N} \mathrm{IH}-3 \mathrm{~T} 3$ cells (Fig. 7B). Together, these data argue that goosecoid, and perhaps Mix.1 and Xotx2 as well, down-regulate Xbra expression through direct transcriptional repression.

$M$ ight these genes repress $X$ bra expression during normal Xenopus development? The case is strong for goosecoid, which appears to be transiently coexpressed with Xbra both in intact embryos (Artinger et al. 1997; al so cf. Gurdon et al. 1994; Vodicka and Gerhart 1995; Ryan et al. 1996) and in activin-treated animal caps (Gurdon et al. 1994, 1995, 1996). Furthermore, Goriely et al. (1996) suggest that goosecoid functions as a repressor, and our own results (Fig. 7B) and those of Artinger et al. (1997) are consistent with this. Of the other two genes, Xotx 2 is expressed maternally and is strongly up-regulated at the onset of zygotic transcription; its gastrula-stage domain of expression is very similar to that of goosecoid, and goosecoid may regulate expression of Xotx2 (Blitz and Cho 1995). The mammalian ortholog of Xotx 2 is able to transactivate from a bicoid target sequence, but in certain contexts some transcription activators are also able to function as repressors (Roberts and Green 1995). Finally, Mix.1 (Rosa 1989) and its pseudoall el e Mix.2 (Vize 1996) are both expressed in the endoderm and mesoderm of the gastrula-stage embryo (see The Xenopus mol ecular marker resource; URL http://vize222.zo.utexas.edu/) and overlap with the expression domain of Xbra. The Mix genes may particularly be involved in ensuring that Xbra is not expressed in the vegetal hemisphere of the embryo. Like Otx2, M ix.1 has been suggested to function as a transcriptional activator (M ead et al . 1996), but, particularly in the presence of goosecoid, with which it can bind DN A cooperatively (Wilson et al. 1993), it may also act as a repressor.

\section{Conclusion}

Overall, our results are consistent with the simplest model imaginable to explain the response of Xbra to different concentrations of activin. At low doses, activin induces expression of Xbra. At higher concentrations, it al so activates expression of genes such as goosecoid and Mix.1. These homeodomain-containing proteins then repress transcription of Xbra to give the observed off-onoff pattern that is observed as the concentration of activin is increased.

\section{Materials and methods}

Construction and screening of a size-selected phage $\lambda$ genomic library

Attempts to isolate genomic clones containing the first exon of Xbra by screening conventional genomic libraries were unsuccessful. We therefore made a library from size-selected restriction fragments known to contain $5^{\prime}$ exons. These were identified by hybridizing a fragment containing the first $350 \mathrm{bp}$ of Xbra cDN A to restriction digests of genomic DN A. BamHI fragments ranging from $4 \mathrm{~kb}$ to $6 \mathrm{~kb}$ were then isolated from an agarose gel and cloned into BamHI-digested Lambda ZapExpress vector (Stratagene). The resulting library was screened at high stringency using the first $350 \mathrm{bp}$ of Xbra cDN A, and two identical clones, 3A1 and 3B1, were isolated.

Primer extension analysis

An oligonucleotide primer complementary to nucleotides +110 to +129 in Xbra2 was end-label ed using $\left[\gamma^{-}{ }^{32}\right.$ P]ATP and T 4 polynucleotide kinase. After purification, the labeled primer was mixed with $50 \mu \mathrm{g}$ total $\mathrm{RNA}$ in $0.4 \mathrm{M} \mathrm{KCl}$ and incubated at $70^{\circ} \mathrm{C}$ for $5 \mathrm{~min}$ followed by $50^{\circ} \mathrm{C}$ for $1 \mathrm{hr}$. N ucleic acids were precipitated with ethanol, resuspended in water, and reverse-transcribed with Superscript II reverse transcriptase (Life Sciences). RN ase $A$ was added to $0.1 \mathrm{mg} / \mathrm{ml}$, and after $10 \mathrm{~min}$ at room temperature CDNA was analyzed by denaturing PAGE.

Plasmid constructs

Luciferase-based vectors A Spel-Bcll fragment containing 53 bp of exon 1 and $2.1 \mathrm{~kb}$ of $5^{\prime}$-flanking sequence was isolated from $3 \mathrm{~A} 1$ and subcloned into the promoterless luciferase vector pGL2Basic (Promega) to generate Xbra2.pGL2. One-kilobase and 150-bp deletion constructs were made using Pstl and Sacl, respectively.

A finer deletion series of the Xbra2 flanking sequence was generated using the polymerase chain reaction, using the same $3^{\prime}$ primer (nucleotides +34 to +48 ) in all cases and various $5^{\prime}$ primers. A $-381 /+54$ fragment was transferred into the Renilla luciferase vector pRLN ull (Promega) to generate the plasmid used in Figure 7A. Antennapedia and Bicoid sites in -381.Xbra2 were mutated using the Chameleon kit (Stratagene) and oligonucleotide 5'-GACTTGCAATTGATTCCCAGGATCCTCCATAGAGCT $-3^{\prime}$. Fragments $(-381 /-150)$ from the wild-type and 
mutant -381.Xbra2 plasmids were removed with Sacl and cloned into pGL3Promoter (Promega).

Human $\beta$-globin-based vector The luciferase gene of Xbra2.pGL2 was removed by digestion with HindlII and Sall and replaced with the $\beta$-globin gene isolated from p128. $\beta / C$ (Mohun et al. 1989).

GFP-based vector A HindlII-BamHI cDNA fragment encoding GFP (Zernicka-Goetz et al. 1996) was used to replace the luciferase gene in a pGL3 Promoter (Promega) construct carrying $2.1 \mathrm{~kb}$ of the Xbra2 promoter.

Vectors used for normalization pSV. $\beta$-galactosidase contains the SV40 early promoter and enhancer driving lacZ (Promega). pEF- $1 \alpha . \beta$-galactosidase contains the EF- $1 \alpha$ promoter derived from the plasmid pXEX (Johnson and Krieg 1994). This drives higher levels of lacZ than pSV. $\beta$-galactosidase. pRL-SV (Renilla luciferase under the control of the SV40 promoter and enhancer) and $\mathrm{pRL}-\mathrm{CMV}$ were from Promega.

\section{Xenopus embryo culture, microinjection, and transgenics}

Xenopus laevis embryos were obtained according to Smith and Slack (1983) and staged according to Nieuwkoop and Faber (1967). Animal caps were dissected at stage 8, and they were cultured in 75\% NAM (Slack 1984). Where FGF-2 (25 ng/ml) was included in the medium, bovine serum al bumin was added to $0.1 \%$. Embryos were injected with RN A as described (Smith 1993).

Xbra2 reporter constructs were injected in circular or linearized form; reference plasmids were injected in circular form. Embryos were microinjected at the one- or two-cell stage with $10-30 \mathrm{pg}$ of $\mathrm{Xbra2}$ reporter DN A together with $80 \mathrm{pg}$ of pSV. $\beta$ galactosidase or $80 \mathrm{pg}$ of $\mathrm{pEF}-1 \alpha-\beta$-galactosidase, or $10 \mathrm{pg}$ of pRL-SV.

Transgenic embryos were generated as described by Amaya and Kroll (1997) using Mlul-digested Xbra2.GFP.

\section{RNase protection assays}

RN ase protections were performed as described (Smith 1993). Xbra2- $\beta$-gl obin fusion transcripts from Xbra2. $\beta$ g were detected using a probe made from plasmid Xbra2. $3 g c D N A$; details are available on request. To detect transcripts of the endogenous Xbra2 gene, a 370-bp Sacl fragment comprising nucleotides -148 to +222 of Xbra2 was subcloned into pBluescript to generate pSac370.9. This plasmid was linearized with BamHI and transcribed with T7 polymerase. Loading control probe EF-1 $\alpha$ has been described previously (Cunliffe and Smith 1992).

\section{In vitro transcription}

In vitro transcription using SP6 or T7 RN A polymerase was as described by Smith (1993). v-Ras CDNA was the gift of Dr. M. Whitman (Harvard Medical School, Boston, MA). Other clones include MEK $1^{\text {S217E/S221E }}$ (Umbhauer et al. 1995), Xenopus activin B (Thomsen et al. 1990), Xotx2 and Xotx2 K $\rightarrow E$ (Pannese et al. 1995), and goosecoid (Cho et al. 1991). Mix.1 cDN A (gift of F. Rosa, Ecole N orwale Supérieure, Paris, France) was cloned into pSP64TXB (a modified form of pSP64T prepared by Dr. M. Tada); the resulting plasmid was linearized with EcoRI and transcribed with SP6 polymerase. Amounts of RN As used in injections were v-Ras, 100 pg; M EK $1^{\text {S217E/S221E }} 1$ ng; activin B, 1-100 pg (see legends to Figs. 3 and 4); goosecoid, Mix.1, Xotx2, and Xotx2 $\mathrm{K} \rightarrow \mathrm{E}, 0.5 \mathrm{ng}$ per blastomere.
Whole-mount in situ hybridization

Whole-mount in situ hybridization to al bino Xenopus embryos was according to Harland (1991) except that the substrate used for the chromogenic reaction was Boehringer $M$ annheim Purple AP Substrate. Xbra2 transcripts were detected using the plasmid pSac370.9AEM; details are available on request. A probe specific for Xbra was made by digesting pXT 1 (Smith et al. 1991) with Stul and transcribing with T7 RN A polymerase. A probe specific for GFP was made by cloning a blunt-ended HindIIIBamHI GFP fragment (Zernicka-Goetz et al. 1996) into Stuldigested pCS2+ (Rupp et al. 1994).

\section{Luciferase and $\beta$-galactosidase assays}

When firefly luciferase assays were performed using $\beta$-gal actosidase for normal ization, embryos ( 5) or animal caps $(\sim 20)$ were frozen on dry ice and then lysed in 5-10 volumes of lysis buffer (Promega). The lysate was clarified by brief centrifugation; $40 \%$ was assayed for luciferase activity using the Promega Luciferase Assay System, and the remaining $60 \%$ was assayed for $\beta$-gal actosidase activity (Sambrook et al. 1989).

In experiments where Renilla luciferase was used for normalization, dual-Iuciferase assays were performed according to the manufacturer's recommendations (Promega). Twelve to 20 animal caps per sample were lysed in $30-50 \mu$ l of Iysis buffer; 0.2 to 0.5 -animal cap equivalents were used in measurements of luciferase activity.

\section{Electrophoretic mobility-shift assay}

Proteins for use in binding reactions were translated in the TNT coupled transcription-translation system (Promega). All four proteins translated with similar efficiency, as assessed by incorporation of ${ }^{35}$ S]methionine and analysis by SDS-PAGE. One microliter of translation reaction was used in each binding reaction, which included $12 \mathrm{~mm} \mathrm{HEPES}$ at $\mathrm{pH} 7.6,60 \mathrm{~mm} \mathrm{KCl}, 0.5$ $\mathrm{mM}$ dithiothreitol (DTT), $3 \mathrm{~mm}$ spermidine, $0.5 \mathrm{~mm}$ PM SF, $12 \%$ glycerol, $3 \mu \mathrm{g}$ of pBluescript KS as a nonspecific DN A competitor, and $\sim 0.4 \mathrm{ng}\left(5 \times 10^{4}-7 \times 10^{4} \mathrm{cpm}\right)$ of ${ }^{32} \mathrm{P}$-label ed probe. Probe was made by annealing oligonucleotides $5^{\prime}$-TCGAGCAATTAAATTCCCAGGATTATC and 5'-TCGAGATAATCCTGGGAATTTAATTGC and labeling them with Klenow enzyme in the presence of [ $\left.{ }^{32} \mathrm{P}\right] \mathrm{dCTP}, \mathrm{dATP}$, dTTP, and dGTP (Sambrook et al. 1989). Nucleotides shown in italics are not derived from Xbra2 sequences. Binding reactions were preincubated for $20-$ $25 \mathrm{~min}$ at room temperature, after which probe was added. After a further $10 \mathrm{~min}$ at room temperature, samples were analyzed on a $4 \%$ polyacrylamide gel.

\section{Cell culture and transfections}

NIH-3T 3 mouse fibroblasts were cultured in Dulbecco's modified Eagle medium (DMEM) (Sigma) supplemented with 10\% newborn calf serum, $2 \mathrm{~mm}$ L-glutamine, $100 \mathrm{U} / \mathrm{ml}$ of penicillin, and $0.1 \mathrm{mg} / \mathrm{ml}$ of streptomycin. Calcium-phosphate transfections were performed as described (Sambrook et al. 1989) in six-well plates. A total of $5 \mu \mathrm{g}$ of DNA per well was used: $4 \mu \mathrm{g}$ of pCDNA3 or PCDNA3-goosecoid, $0.5 \mu \mathrm{g}$ of Xbra2 reporter plasmid, and $0.5 \mu \mathrm{g}$ of reference plasmid (either pRL-CMV or pRL-SV40). Cells were analyzed for luciferase activities 3 days after transfection as described above. Each sample was transfected in duplicate. goosecoid CDN A (Blumberg et al. 1991) was cloned into the pcDN A 3 vector (containing the CMV promoter/ enhancer; Invitrogen) using EcoRI and Xhol. 


\section{Acknowledgments}

This work is supported by the Medical Research Council. We thank members of our laboratory for discussions, M asa T ada for help with in situs, Tim Mohun for advice, and members of the NIMR Molecular Immunology Division for use of their luminometer. We are also very grateful to Ken Cho (University of California, Irvine, CA) for a helpful discussion which directed us to analysis of goosecoid, to Enrique A maya (Wellcome/CRC, Cambridge, UK) for advice on making transgenic Xenopus, and to Richard Treisman (Imperial Cancer Research Foundation, London, UK) for advice on transcription. B.V.L. was supported by the ESF Developmental Biology Programme and by the Howard Hughes Medical Institute (HHMI), V.C. was supported by EC BioTech grant PL920102, M.U. was supported by a CEC Human Capital Mobility grant, W.L. is supported by Boehringer-Ingel heim Fonds, and J.C.S. is an International Scholar of the $\mathrm{HHMI}$.

The publication costs of this article were defrayed in part by payment of page charges. This article must therefore be hereby marked "advertisement" in accordance with 18 USC section 1734 solely to indicate this fact.

\section{References}

Amaya, E. and K.L. Kroll. 1997. A method for generating transgenic frog embryos. In Methods in cell biology. Molecular embryology: Methods and protocols (ed. P. Sharpe and I. M ason), Humana Press, Inc., T otowa, NJ. (In press).

Artinger, M., I. Blitz, K. Inoue, U. Tran, and K.W.Y. Cho. 1997. Interaction of goosecoid and brachyury in Xenopus mesoderm patterning. Mech. Dev. 65: 187-196.

Asashima, M., H. N akano, K. Shimada, K. Kinoshita, K. Ishii, H. Shibai, and N. Ueno. 1990. Mesodermal induction in early amphibian embryos by activin A (erythroid differentiation factor). Roux's Arch. Dev. Biol. 198: 330-335.

Blitz, I.L. and K.W.Y. Cho. 1995. Anterior neurectoderm is progressively induced during gastrulation: The role of the Xenopus homeobox gene orthodenticle. Development 121: 9931004.

Blumberg, B., C.V.E. Wright, E.M. De Robertis, and K.W.Y. Cho. 1991. Organizer-specific homeobox genes in Xenopus Iaevis embryos. Science 253: 194-196.

Cho, K.W.Y., B. Blumberg, H. Steinbeisser, and E.M. De Robertis. 1991. M olecular nature of Spemann's organizer: The role of the Xenopus homeobox gene goosecoid. Cell 67: 1111-1120.

Clements, D., H.C. Taylor, B.G. Herrmann, and D. Stott. 1996. Distinct regulatory control of the Brachyury gene in axial and non-axial mesoderm suggests separation of mesodermal lineages early in mouse gastrulation. Mech. Dev. 56: 139149.

Conlon, F.L., S.G. Sedgwick, K.M. Weston, and J.C. Smith. 1996. Inhibition of Xbra transcription activation causes defects in mesodermal patterning and reveal s autoregulation of Xbra in dorsal mesoderm. Development 122: 2427-2435.

Corbo, J.C., M. Levine, and R.W. Zeller. 1997. Characterization of a notochord-specific enhancer from the Brachyury promoter region of the ascidian, Ciona intestinalis. Development 124: 589-602.

Cunliffe, V. and J.C. Smith. 1992. Ectopic mesoderm formation in Xenopus embryos caused by widespread expression of a Brachyury homologue. Nature 358: 427-430.

- - . 1994. Specification of mesodermal pattern in Xenopus laevis by interactions between Brachyury, noggin, and Xwnt-8. EMBO J. 13: 349-359.

Dale, L. and J.M. Slack. 1987. Fate map for the 32-cell stage of Xenopus laevis. Development 99: 527-551.
Desplan, C., J. Theis, and P.H. O'Farrell. 1988. The sequence specificity of homeodomain-DNA interaction. Cell 54: 1081-1090.

Dyson, S. and J.B. Gurdon. 1996. Activin signalling has a necessary function in Xenopus early development. Curr. Biol. 7: 81-84.

Goriely, A., M. Stella, C. Coffinier, D. Kessler, C. Mailhos, S. Dessain, and C. Desplan. 1996. A functional homologue of goosecoid in Drosophila. Development 122: 1641-1650.

Green, J.B.A., H.V. N ew, and J.C. Smith. 1992. Responses of embryonic Xenopus cells to activin and FGF are separated by multiple dose thresholds and correspond to distinct axes of the mesoderm. Cell 71: 731-739.

Green, J.B.A., J.C. Smith, and J.C. Gerhart. 1994. Slow emergence of a multithreshold response to activin requires cellcontact-dependent sharpening but not prepattern. Development 120: 2271-2278.

Green, J.B.A., T.L. Cooke, J.C. Smith, and R.M. Grainger. 1997. Anteroposterior neuraxis specification induced by activininduced mesoderm. Proc. Natl. Acad. Sci. 94: 8596-8601.

Gurdon, J.B., P. Harger, A. Mitchell, and P. Lemaire. 1994. Activin signalling and response to a morphogen gradient. Nature 371: 487-492.

Gurdon, J.B., A. Mitchell, and D. Mahony. 1995. Direct and continuous assessment by cells of their position in a morphogen gradient. Nature 376: 520-521.

Gurdon, J.B., A. Mitchell, and K. Ryan. 1996. An experimental system for analyzing response to a morphogen gradient. Proc. Natl. Acad. Sci. 93: 9334-9338.

Halpern, M.E., R.K. Ho, C. Walker, and C.B. Kimmel. 1993. Induction of muscle pioneers and floor plate is distinguished by the zebrafish no tail mutation. Cell 75: 99-111.

Hanes, S.D. and R. Brent. 1991. A genetic model for interaction of the homeodomain recognition helix with DNA. Science 251: 426-430.

Harland, R.M. 1991. In situ hybridization: An improved whole mount method for Xenopus embryos. Methods Cell Biol. 36: $675-685$.

Herrmann, B.G., S. Labeit, A. Poutska, T.R. King, and H. Lehrach. 1990. Cloning of the $T$ gene required in mesoderm formation in the mouse. Nature 343: 617-622.

Huang, H.-C., L.C. Murtaugh, P.D. Vize, and M. Whitman. 1995. Identification of a potential regulator of early transcriptional responses to mesoderm inducers in the frog embryo. EMBO J. 14: 5965-5973.

Johnson, A.D. and P.A. Krieg. 1994. pXeX, a vector for efficient expression of cloned sequences in Xenopus embryos. Gene 147: 223-226.

Jones, C.M., N. Armes, and J.C. Smith. 1996. Signalling by TGF- $\beta$ family members: Short-range effects of $\mathrm{Xnr}-2$ and BM P-4 contrast with the long-range effects of activin. Curr. Biol. 6: 1468-1475.

Kaufmann, E., H. Paul, H. Friedle, A. M etz, M. Scheucher, J.H. Clement, and W. Knöchel. 1996. Antagonistic actions of activin A and BM P-2/4 control dorsal lip-specific activation of the early response gene XFD-1' in Xenopus laevis embryos. EMBO J. 15: 6739-6749.

Kispert, A. and B.G. Herrmann. 1993. The Brachyury gene encodes a novel DN A binding protein. EMBO J. 12: 3211-3220.

Kispert, A., B. Korschorz, and B.G. Herrmann. 1995a. The T protein encoded by Brachyury is a tissue-specific transcription factor. EMBO J. 14: 4763-4772.

Kispert, A., H. Ortner, J. Cooke, and B.G. Herrmann. 1995b. The chick Brachyury gene: Developmental expression pattern and response to axial induction by localized activin. Dev. Biol. 168: 406-415. 
Kobel, H.R. and L. Du Pasquier. 1986. Genetics of polyploid Xenopus. Trends Genet. 3: 310-315.

Lustig, K.D., K.L. Kroll, E.E. Sun, and M.W. Kirschner. 1996. Expression cloning of a Xenopus T-rel ated gene (Xombi) involved in mesodermal patterning and blastopore lip formation. Development 122: 4001-4012.

Mead, P.E., I.H. Brivanlou, C.M. Kelley, and L.I. Zon. 1996. BM P-4-responsive regulation of dorsal-ventral patterning by the homeobox protein Mix.1. Nature 382: 357-360.

Mohun, T.J., M.V. Taylor, N. Garrett, and J.B. Gurdon. 1989. The CArG promoter sequence is necessary for muscle-specific transcription of the cardiac actin gene in Xenopus embryos. EMBO J. 8: 1153-1161.

N ieuwkoop, P.D. and J. Faber. 1967. Normal table of Xenopus laevis (Daudin). N orth Holland, Amsterdam, The N etherlands.

Nonchev, S., M. Maconochie, C. Vesque, S. A paricio, L. ArizaM CN aughton, M. Manzanares, K. Maruthainar, A. Kuroiwa, S. Brenner, P. Charnay, and R. Krumlauf. 1996. The conserved role of Krox-20 in directing Hox gene expression during vertebrate hindbrain segmentation. Proc. Natl. Acad. Sci. 93: 9339-9345.

O'Reilly, M.-A.J., J.C. Smith, and V. Cunliffe. 1995. Patterning of the mesoderm in Xenopus: Dose-dependent and synergistic effects of Brachyury and Pintallavis. Development 121: 1351-1359.

Pannese, M., C. Polo, M. Andreazzoli, R. Vignali, B. Kablar, G. Barsacchi, and E. Boncinelli. 1995. The Xenopus homologue of Otx2 is a maternal homeobox gene that demarcates and specifies anterior body regions. Development 121: 707-720.

Rao, Y. 1994. Conversion of a mesodermalizing molecule, the Xenopus Brachyury gene, into a neural izing factor. Genes \& Dev. 8: 939-947.

Reilly, K.M. and D.A. Melton. 1996. Short-range signaling by candidate morphogens of the TGF beta family and evidence for a relay mechanism of induction. Cell 86: 743-754.

Roberts, S.G. and M.R. Green. 1995. Dichotomous regulators. Nature 375: 105-106.

Rosa, F.M. 1989. Mix.1, a homeobox mRN A inducible by me soderm inducers, is expressed mostly in the presumptive endodermal cells of Xenopus embryos. Cell 57: 965-974.

Ruiz i Altaba, A. and T.M. Jessell. 1992. Pintallavis, a gene expressed in the organizer and midline cells of frog embryos: Involvement in the development of the neural axis. Development 116: 81-93.

Rupp, R.A.W., L. Snider, and H. Weintraub. 1994. Xenopus embryos regulate the nuclear localization of XM yoD. Genes \& Dev. 8: 1311-1323.

Ryan, K., N. Garrett, A. Mitchell, and J.B. Gurdon. 1996. Eomesodermin, a key early gene in Xenopus mesoderm differentiation. Cell 87: 989-1000.

Sambrook, J., E.F. Fritsch, and T. Maniatis. 1989. Molecular cloning: A laboratory manual. Cold Spring Harbor Laboratory Press, Cold Spring Harbor, NY.

Schulte-M erker, S., R.K. Ho, B.G. Herrmann, and C. N üssleinVolhard. 1992. The protein product of the zebrafish homologue of the mouse T gene is expressed in nuclei of the germ ring and the notochord of the early embryo. Development 116: 1021-1032.

Schulte-M erker, S., F.M. van Eeden, M.E. Halpern, C.B. Kimmel, and C. N üsslein-Volhard. 1994. No tail (ntl) is the ze brafish homologue of the mouse T (Brachyury) gene. Development 120: 1009-1015.

Sive, H.L. 1993. The frog prince-ss: A molecular formula for dorsoventral patterning in Xenopus. Genes \& Dev. 7: 1-12.

Slack, J.M.W. 1984. Regional biosynthetic markers in the early amphibian embryo. J. Embryol. Exp. Morphol. 80: 289-319. . 1994. Inducing factors in Xenopus early embryos. Curr. Biol. 4: 116-126.

Smith, J.C. 1993. Purifying and assaying mesoderm-inducing factors from vertebrate embryos. In Cellular interactions in development-A practical approach (ed. D. Hartley), pp. 181-204. Oxford University Press, Oxford, UK.

Smith, J.C. and J.M.W. Slack. 1983. Dorsalization and neural induction: Properties of the organizer in Xenopus Iaevis. J. Embryol. Exp. Morphol. 78: 299-317.

Smith, J.C., B.M.J. Price, N.K. Van, and D. Huylebroeck. 1990. Identification of a potent Xenopus mesoderm-inducing factor as a homologue of activin A. Nature 345: 732-734.

Smith, J.C., B.M.J. Price, J.B.A. Green, D. Weigel, and B.G. Herrmann. 1991. Expression of a Xenopus homolog of Brachyury $(T)$ is an immediate-early response to mesoderm induction. Cell 67: 79-87.

Smith, S.T. and J.B. Jaynes. 1996. A conserved region of engrailed, shared among all en-, gsc-, N k1-, N k2- and msh-class homeoproteins, mediates active transcriptional repression in vivo. Devel opment 122: 3141-3150.

Stennard, F., G. Carnac, and J.B. Gurdon. 1996. The Xenopus T-box gene, Antipodean, encodes a vegetally local ised maternal mRNA and can trigger mesoderm formation. Development 122: 4179-4188.

Tada, M., M.-A.J. O'Reilly, and J.C. Smith. 1997. Analysis of competence and of Brachyury autoinduction by use of hormone-inducible Xbra. Development 124: 2225-2234.

Thomsen, G., T. Woolf, M. Whitman, S. Sokol, J. Vaughan, W. Vale, and D.A. M elton. 1990. Activins are expressed early in Xenopus embryogenesis and can induce axial mesoderm and anterior structures. Cell 63: 485-493.

Treisman, J., E. Harris, D. Wilson, and C. Desplan. 1992. The homeodomain: A new face for the helix-turn-helix? BioEssays 14: 145-150.

Umbhauer, M., C.J. Marshall, C.S. Mason, R.W. Old, and J.C. Smith. 1995. Mesoderm induction in Xenopus caused by activation of MAP kinase. Nature 376: 58-62.

Vize, P.D. 1996. DN A sequences mediating the transcriptional response of the Mix.2 homeobox gene to mesoderm induction. Dev. Biol. 177: 226-231.

Vize, P.D., D.A. M elton, A. Hemmati-Brivanlou, and R.M. Harland. 1991. Assays for gene function in developing Xenopus embryos. Methods Cell Biol. 36: 367-387.

Vodicka, M.A. and J.C. Gerhart. 1995. Blastomere derivation and domains of gene expression in the Spemann Organizer of Xenopus laevis. Devel opment 121: 3505-3518.

Watabe, T., S. Kim, A. Candia, U. Rothbacher, C. Hashimoto, K. Inoue, and K.W.Y. Cho. 1995. M olecular mechanisms of Spemann's organizer formation: Conserved growth factor synergy between Xenopus and mouse. Genes \& Dev. 9: 30383050.

Weeks, D.L. and D.A. Melton. 1987. A maternal mRNA localized to the vegetal hemisphere in Xenopus eggs codes for a growth factor related to TGF-beta. Cell 51: 861-867.

Wilson, D., G. Sheng, T. Lecuit, N. Dostatni, and C. Desplan. 1993. Cooperative dimerization of Paired class homeo domains on DNA. Genes \& Dev. 7: 2120-2134.

Zernicka-Goetz, M., J. Pines, K. Ryan, K.R. Siemering, J. Haseloff, M.J. Evans, and J.B. Gurdon. 1996. An indelible lineage marker for Xenopus using a mutated green fluorescent protein. Development 122: 3719-3724.

Zhang, J. and M.L. King. 1996. Xenopus VegT RN A is localized to the vegetal cortex during oogenesis and encodes a novel T-box transcription factor involved in mesodermal patterning. Development 122: 4119-4129. 


\title{
Errata
}

Genes \& Development 11: 3265-3276 (1997)

The Xenopus Brachyury promoter is activated by FGF and low concentrations of activin and suppressed by high concentrations of activin and by paired-type homeodomain proteins

Branko V. Latinkić, M uriel U mbhauer, Kathy A. N eal, Walter Lerchner, James C. Smith, and Vincent Cunliffe

The first author's name was spelled incorrectly in this article. It is correct here.

Genes \& Development 12(6) March 15, 1998

The cover headline and caption for this issue were incorrect. The headl ine should read:

Regulation of the cell division protein FtsZ in Caulobacter.

The correct caption is printed bel ow.

Cover Caulobacter crescentus and the cell division initiation protein FtsZ through the cell cycle. Shown are electron micrographs of Caulobacter (top) and immunofluorescence analysis of FtsZ (bottom) at different stages through the cell cycle. The cell cycle initiates with a swarmer cell (left) that contains a single polar flagel lum (wavy line), which differentiates into a stalked cell (third from left) by shedding the flagellum and synthesizing a stal $k$ at the same pole. The predivisional cell (fourth from left) contains a single flagellum synthesized at the pole opposite the stalk. Cell division produces a swarmer cell and stalk cell (right). The replication-competent stalk cell contains FtsZ, whereas the replication-incompetent swarmer cell lacks FtsZ. (For details, see Kelly et al., p. 880.)

Genes \& Development 12: 782-796 (1998)

\author{
Helios, a T cell-restricted Ikaros family member that quantitatively associates with I karos at centromeric \\ heterochromatin \\ Kyungmin Hahm, Bradley S. Cobb, Aaron S. McCarty, Karen E. Brown, Christopher A. Klug, Robert Lee, \\ Koichi Akashi, Irving L. Weissman, A manda G. Fisher, and Stephen T. Smale
}

The name of Irving L. Weissman was spelled incorrectly in the Table of Contents of this issue. It is correct here.

\section{Genes \& Development 12(7)}

The cover headline and caption for this issue were incorrect. The headl ine should read: Role of CBP in C. elegans embryonic differentiation

The correct caption is printed below.

Cover Expression and phenotypic analysis of CBP-1 in Caenorhabditis elegans. Shown are $\mathrm{N}$ omarski images of wild-type (top left) and cbp-I mutant (top right) embryos. The mutant embryo produces many small cells and shows no evidence of mesodermal, endodermal, or hypodermal tissue organization. The small cells are reminiscent of neuronal cells, and immunostaining with antibodies against UNC-86, a neuronal differentiaton-specific protein, of wild-type (bottom left) and cbp-I (bottom right) reveals an increase in the number of neuronal precursors in mutant embryos. (For details, see Shi and Mello, p. 943). 


\section{Erratum}

Genes \& Development 12: 304-315 (1998)

inscuteable and numb mediate asymmetric muscle progenitor cell divisions during $D$ rosophila myogenesis Ana Carmena, Bernadette Murugasu-Oei, Devi Menon, Fernando Jiménez, and William Chia

Figure 6 of this article should have appeared in color. The correct figure and legend appear bel ow.

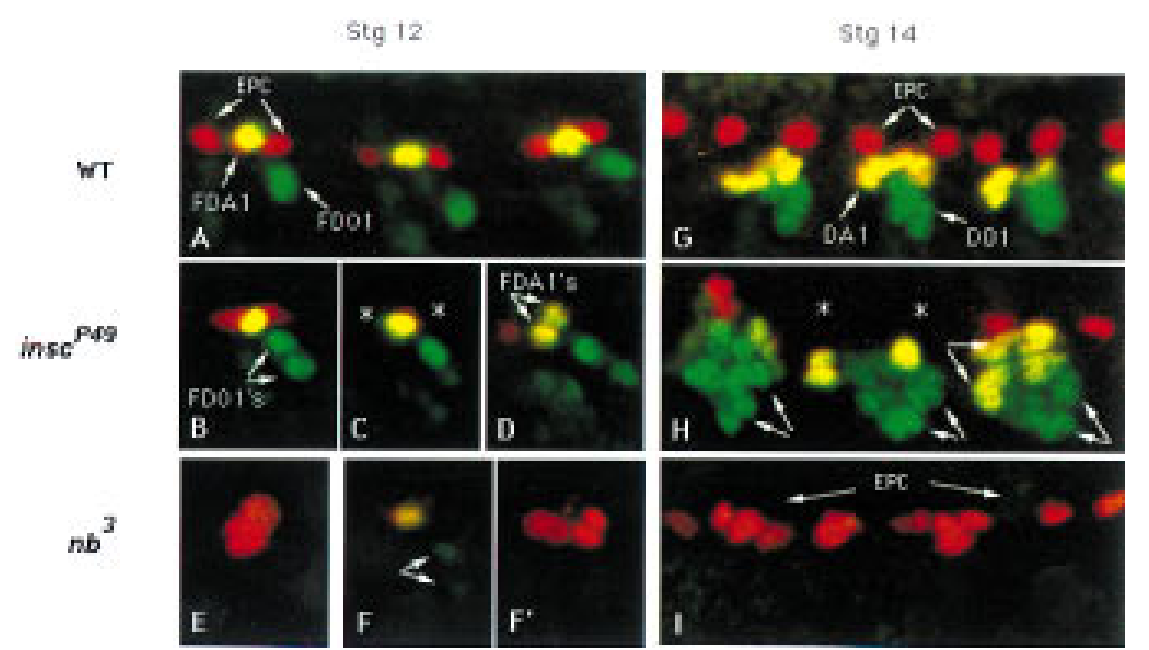

Figure 6. The fate of the progeny from $\mathrm{P} 2$, P15, and P17 progenitors in wild-type, insc $^{\text {P49, }}$, and numb ${ }^{3}$ embryos. Embryos were double stained for Eve (red) and $\mathrm{Kr}$ (green). Stage $12\left(A-F^{\prime}\right)$ and stage $14(G-I)$ wild-type $(A, G)$, insc ${ }^{P 49}(B-D, H)$, and $n b^{3}$ $\left(E-F^{\prime}, I\right)$ embryos are shown. (A) Three consecutive wild-type hemisegments at midto late-stage 12. At this stage, the two EPC (red) are already present. The $\mathrm{Kr}^{+} \mathrm{Eve}^{+}$ FDA 1 (yellow) and the $\mathrm{Kr}^{+} \mathrm{FDO} 1$ (green) are also evident. (B-D) In insc ${ }^{\mathrm{P} 49}$ embryos, the incomplete expressivity of the mutant phenotype is evident in different hemisegments and is characterized by duplication of FDO1 (B), loss of the two EPC $(C, *)$, and duplication of the FDA 1 (D). (E-F') The opposite phenotype is found in $\mathrm{nb}^{3}$ embryos: Two FEPCs are detected at early stage 12,

which are enlarging to divide (E), and no putative FDA 1 and FDO 1 are detected that express Eve and/or Kr. At mid-stage 12, extra EPCs are detected $\left(F^{\prime}\right)$. $\left(F, F^{\prime}\right)$ Two different focal planes of the same mutant hemisegment at mid-stage 12. (F) The FDA 1 (yellow cells) is losing Eve and $\mathrm{Kr}$ expression; likewise, $\mathrm{Kr}$ expression is decaying in both siblings produced by division of P17 (arrows). (G) The characteristic pattern of EPC and precursors of DA 1 and DOI in a wild-type embryo at stage 14. (H) In an insc ${ }^{\text {P49 }}$ embryo, Ioss of EPC $\left(^{*}\right)$ and duplication of the precursors of muscles DA 1 (yellow syncytia, arrows) and DO1 (green syncytia, arrows) are evident. (I) The opposite phenotype is observed in a $\mathrm{nb}^{3}$ embryo; extra EPCs and the absence of DA1 and DO1 muscle precursors. 


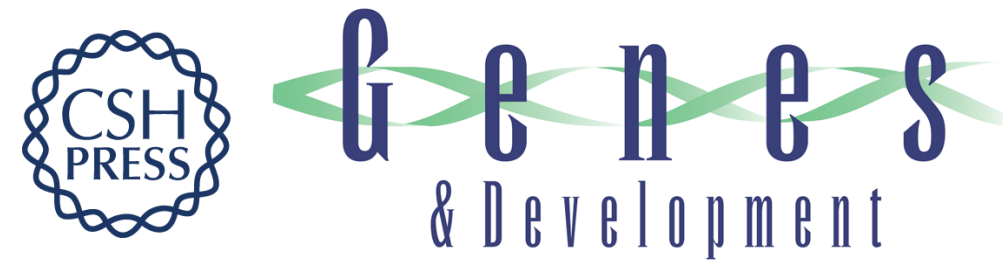

\title{
The Xenopus Brachyury promoter is activated by FGF and low concentrations ofactivinandsuppressed by high concentrationsof activin and by paired-type homeodomain proteins
}

Brancko V. Latinkic, Muriel Umbhauer, Kathy A. Neal, et al.

Genes Dev. 1997, 11:

Access the most recent version at doi:10.1101/gad.11.23.3265

\author{
Related Content Errata for vol. 11, p. 3265 \\ Genes Dev. April , 1998 12: 1240 \\ References This article cites 66 articles, 28 of which can be accessed free at: \\ http://genesdev.cshlp.org/content/11/23/3265.full.html\#ref-list-1 \\ Articles cited in: \\ http://genesdev.cshlp.org/content/11/23/3265.full.html\#related-urls \\ License \\ Email Alerting
Service $\begin{aligned} & \text { Receive free email alerts when new articles cite this article - sign up in the box at the top } \\ & \text { right corner of the article or click here. }\end{aligned}$
}

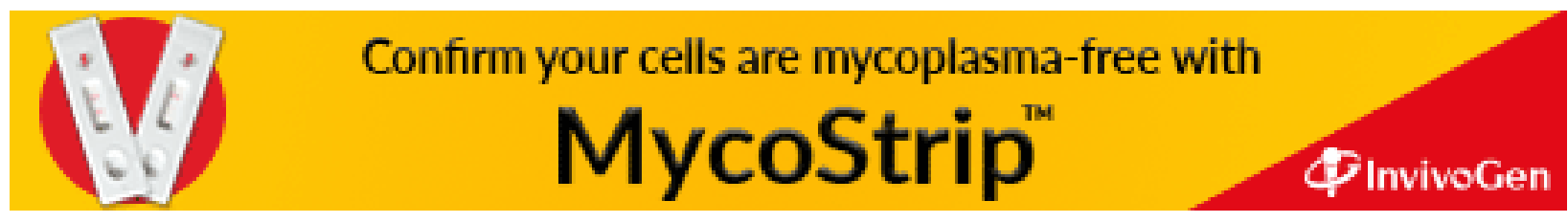

